\title{
He waka eke noa!
}

\section{By Eliza Perkinson, Whitireia Polytechnic, Aotearoa New Zealand}

He uri ahau nō Te Rarawa, me Ngāti Whātua, me Ngāpuhi, me Ngātiwai.

Nō Te Hiku ō Te Ika ōku tūpuna.

Ko Eliza Perkinson tōku ingoa.

Out of the response to Covid-19 emerged a message: he waka eke noa. This whakatauki, which directly translates to mean, "we are all in this together", was used to unite Aotearoa New Zealand in our efforts against the virus. It refers to a waka of collective consciousness guiding us on the same journey. But were we united? Were we truly in this waka (canoe), of five million together?

My experience of this waka was inherently different to others. It was steered by the dictatorship of my 4-year-old son while I frantically bailed water from the destruction created by two riotous boys and being ignored by a teenage daughter. Although I could be forgiven for self-isolating in the bathroom while "collecting myself" or allowing screen-time for an undisclosed and irresponsible amount of time, I still found myself comparing my waka to others. I would fabricate scenarios in my mind of a wellkept waka with all the provisions and latest gadgets. I also took part in a social media ruse to feature images of a wholesome family and well-structured schooling routines. I became a student, teacher, counsellor, referee, and master chef. Although I was not cut out to be a teacher and lived in a house full of food critics, my house was filled with laughter and memories that we will share of our experience of isolation "survival". This will become my children's stories of "when I was young" to tell their children.

As a student, I feared this disorganised waka of chaos would be exposed by required video conferencing of "doom", more commonly known as zoom. My fears were justified, my attempt at an assignment presentation was thwarted by the efforts of our "dictator" although understandably so, considering it was snack time. My economic status was laid bare by my uniquely identifiable curtains found only in the homes managed by Housing New Zealand. Assignments came thick and fast and my studies took precedence, I had to adapt and overcomeafter all, Māori are resilient right? We are not unacquainted with adversity, and I was out to prove just that. I was determined to hoe this waka to academic excellence, although this meant losing precious cargo-time with my tamariki and connections with whannau and friends. We all made sacrifices during this time, the lives and livelihoods of many were lost to the virus.

New Zealanders may have been on the same journey to escape the virus, but we were all in very different waka. Covid-19 brought to light pre-existing inequalities within society and again raised the issue of my least favourite term-consultation. Consulting health professionals and consulting Māori all seemed to be yet another box ticking exercise by the government before implementing its response. The level two legislation left no room for tino rangatiratanga and dissipated all intentions of collaboration. Māori were back to consultation and advice from experts was ignored. The cultural importance of grieving collectively and the ability to implement tikanga to manage distancing on marae was discounted. I was concerned. Would I have to put the tūpapaku of a loved one on ice and alone while being so far from my whenua, my urupā, and whānau? Or would I be forced to further disregard my cultural beliefs and decide to have them cremated. I was inspired by the gracefulness of other whannau who lost a loved one during this time and
AOTEAROA NEW ZEALAND SOCIAL WORK 32(2), 71-72.

CORRESPONDENCE TO: Eliza Perkinson Eliza.Perkinson@ whitireianz.ac.nz 
how they have navigated this space to protect against further transmission.

Inequality existed long before the virus and will continue to exist for as long as we ignore this fact. The decisive action from government was largely commendable and demonstrated its ability to provide effective responses to adverse situations, and, to an extent, its ability to collaborate with Māori. It should not take a virus to make us work together to alleviate economic inequalities and its negative impacts. As a wahine Māori, I was already isolated from my whenua, my culture, good healthcare and educational opportunities long before the virus took hold. If we are to truly believe that we are "in this together", we need to also understand that we are not. Through this experience I have learned that although my waka is small and grossly unorganised, we can navigate the choppiest seas, and there should always be space for tino rangatiratanga.

He moana pukepuke e ekengia e te waka. "A choppy sea can be navigated by a waka".

\section{Glossary}

Whakatauki

Māori proverb

Hoe Paddle

Waka Canoe

Tino-rangatiratanga Māori sovereignty/ self-determination

Tikanga Customary practices/ system of values

Tūpāpaku Body of deceased person

Whenua Ancestral land

Urupā Burial ground

Whānau Family- extended

Wahine Woman 